\title{
FUNDAL LESIONS IN SARCOIDOSIS
}

\author{
E. KOHNER, B.Sc., M.R.C.P. \\ Registrar, Medical Ophthalmology Unit, \\ Lambeth Hospital, S.E.11.
}

\author{
G. GreenberG, B.Sc., M.B., B.S. \\ Research Assistant, Sarcoidosis Unit, \\ Royal Northern Hospital, N.7.
}

INVOLVEMENT of the eye occurs in approximately one-quarter of patients with sarcoidosis. In various large series the figure varies from $28 \%$ to $50 \%$ (Table 1). The commonest type of involvement is anterior uveitis, occurring in from $23 \%$ to $90 \%$ of patients with ocular involvement in these series. Not surprisingly, posterior uveitis is less frequently discernible because it is hidden by inflammation of the anterior segment of the eye. However, in recent years the introduction of corticosteroids has changed the natural history of ocular sarcoidosis because these drugs readily control acute iridocyolitis. Thus when disease of the anterior segment is rapidly controlled it is possible to see the fundus oculi at a much earlier stage when sarcoid lesions are still present. We feel that this will become increasingly evident in the future. In a series of 450 patients with sarcoidosis attending the Royal Northern Hospital Sarcoidosis Clinic, 16 have been observed with fundal lesions (Table 2). Apart from the eye lesions they do not differ significantly in any parameter.

\section{Choroiditis}

In our series, 11 patients exhibited choroiditis. In posterior uveitis the primary lesion is always in the choroid. There are two distinct forms of sarcoid choroiditis. One is a non-specific type which cannot be distinguished ophthalmoscopically from any other form of posterior uveitis (Crick, 1961, Green and Kennedy, 1957). In this form the abnormal findings on ophthalmoscopy are usually restricted to several welldefined whitish nodules, juxtapapillary or peripheral in distribution; if the disease is active the outlines of these nodules may be obscured by inflammatory exudate from the surrounding tissues (Dressler and Wagner, 1941, Roberts and Neilson, 1945, Gifford and Crowther, 1949, Morax, 1956, Bruntse, 1958 and Hudelo, 1962).

In the specific type of choroiditis, thought to occur in sarcoidosis only, yellowish-white patches of irregular shape and size are distributed along the retinal vessels, usually the veins. These lesions were first described by Walsh (1939). Franceschetti and Babel in 1949 used the term choroido-retinitis "en tache de bougie" to describe this appearance which has also been described by several other writers (Levitt, 1941, Lewis, 1950, Mackensen, 1952, Morax, 1956, Gould and Kaufman, 1961 and Hudelo, 1962). These nodules nearly always constrict the retinal vessels along which they are distributed and cause perivasculitis.

TABLE I

MANIFESTATIONS OF OCULAR SARCOIDOSIS IN VARIOUS SERIES
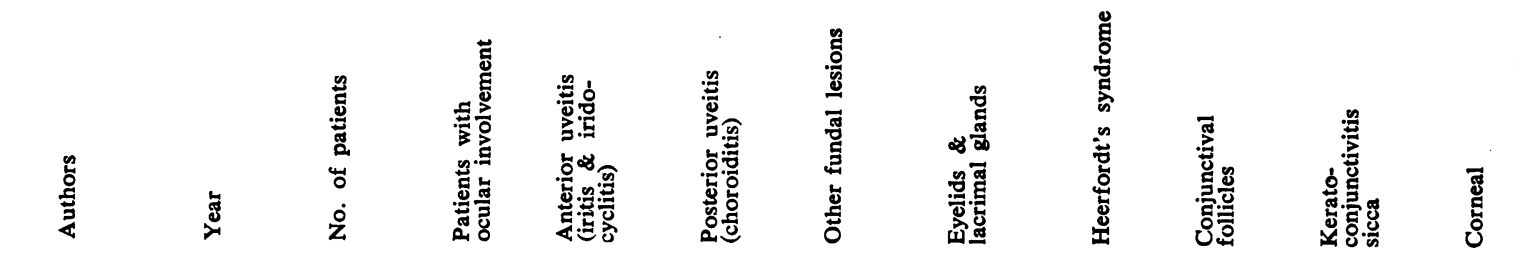

Gifford

and

Longcope

and

Freiman

Crick

James

et al

1949

30

No. $\%$

1952

1961

142

$10 \quad 33$

$\%$ No.

$\%$ No.

$\%$ No.

$\%$ No.

$\%$ No. $\%$ No. $\%$ No. $\%$

1964

185

$53 \quad 37$

990

110

0 220

$0 \quad 0$

$7 \quad 70$

$\begin{array}{llll}0 & 0 & 7 & 70\end{array}$

442
799

$\begin{array}{llll}93 & 50 & 21 & 23\end{array}$

12

$\begin{array}{llll}3 & 6 & 10 & 15\end{array}$

00

$\begin{array}{rr}123 & 28 \\ 279 & 35 \%\end{array}$

$\begin{array}{rr}89 & 72 \\ 147.3 \%\end{array}$

11 . 9 \%

$\begin{array}{ll}1 & .5 \\ 5 & .5 \%\end{array}$

00

$13 \quad 14$

$\begin{array}{llllll}1 & 2 & 6 & 12 & 5 & 10\end{array}$

$\begin{array}{llllll}5 & 5 & 58 & 62 & 5 & 5\end{array}$

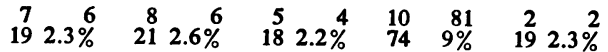


TABLE 2

Clinical, Radiological and IMMUNOLOGICAL Features of 16 Patients WITH Fundal SARCOIDOSIS

$\begin{array}{cc} & \\ & \\ & \\ & \text { Male } \\ & \text { Femal } \\ & 21-30 \\ \text { Age } & 31-40 \\ & \\ & 41-50 \\ & 51-60\end{array}$

Bilateral fundal involvement Unilateral fundal involvement Chest X-ray abnormalities

Enlarged lymph nodes

Positive Kveim test

Negative Mantoux test

$\begin{array}{cc}\text { No. } & \% \\ 7 & 44 \\ 9 & 56 \\ 7 & 44 \\ 5 & 31\end{array}$

$3 \quad 19$

$\begin{array}{lr}1 & 6 \\ 8 & 50\end{array}$

$8 \quad 50$

$10 \quad 63$

$\begin{array}{lr}8 & 50 \\ 11 / 11 & 100\end{array}$

$7 / 12 \quad 58$

Choroido-retinitis may also occur in the nonspecific form of sarcoid choroiditis if the granulomata involve the retina. If the granulomata project into the vitreous the mass is called a "sarcoidoma" (Walsh, 1939, Goldberg and Newall, 1944 and Ozarewski and Bennett, 1952).

Peripheral choroiditis is symptomless. Involvement of the macula will cause blurring and loss of vision. Fundal lesions are painless but an associated anterior lesion may cause pain; the more severe the posterior lesion, the greater the probability that it will be associated with some anterior manifestation of the disease (Geeraets, 1962).

\section{Perivasculitis Retinæ}

This was observed in two of our patients. Retinal perivasculitis, usually periphlebitis, may occur without choroiditis if the sarcoid nodule forms in the vessel wall itself (Gould and Kaufman, 1961, Geeraets, 1962). Marked variation in calibre of affected vessels is seen with white exudate and sheathing along their walls. If the vessel is not obstructed the condition is symptomless; should occlusion occur, perivenous exudates and hæmorrhages will form and may, if extensive, become preretinal and vitreous.

\section{Vitreous Opacities}

These were not seen in any of the patients in this series, although according to Crick they are commonly seen in ocular sarcoidosis. They are globular, greyish-white, and usually found in the lower vitreous near the retina (Landers, 1949, Roberts and Neilson, 1945, Bruntse, 1958). Their origin is not clear; Crick thinks that they are formed in the ciliary body and are carried by gravity to the lower vitreous where a retinal reaction occurs.

\section{Papilloedema}

There were 3 patients with papillœdema Two also had cranial nerve palsies when the presented in a neurological department and had burr-holes made in the course of the invest gation of their raised intra-cranial pressure before a diagnosis of sarcoidosis was consideref. In one case the papillodema was confined the left eye but there was a right 6th nerve palsy.

Meningeal or encephalitic sarcoidosis moly produce raised intra-cranial pressure. Papif lœdema is seen, with a swollen hyperæmic disc with blurred margins, distension of the veins and hæmorrhages and odema extending 8 the macula (Roberts and Neilson, 1945, Coloves, 1948, Fine and Flocks, 1953 and Ross, 1955.

Spread of sarcoid tissue from the meninges or the third ventricle may involve the opt nerve or chiasma. Lesions in the nerve head may present as papillitis (Morax, 1956) or as a pseudo-tumour (Walsh, 1939, Laval, 1952. Alajouanine, 1952, Green, 1957). Meitke (1958) described a pseudo-tumour producing 20 dioptres of swelling of the disc.

\section{Optic Atrophy}

In sarcoidosis, optic atrophy is of the secutive type following papillœdema (Wassy 1939, Klein, Calvert, Joseph and Smith, 19E5.f.

Optic nerve lesions are always associated with visual disturbances. In the presence of papillœdema produced by raised intra-crani]্త্] pressure there may be blurring of vision wi enlargement of the blind spot and constriction of the peripheral fields. In papillitis the blus ring of vision will be transient and there maj be central scotomata. Field loss of varying types depending on the site of the lesion wi be caused by involvement of the optic nerve In optic atrophy and pseudo-tumour the visua loss may be severe.

\section{Course and Treatment}

Fundal sarcoidosis has been insufficient店 recognised and followed for the natural history of this form of the disease to be clear. Untreatef choroiditis may heal within weeks or remain active for months; in either case scar tissue with surrounding pigmentation persists. Juxta papillary and peripheral lesions heal with litt or no residual visual disturbance, but maculáp and perimacular lesions leave permanent ing pairment of vision.

Preretinal and vitreous hæmorrhages usuali absorb when the perivasculitis settles though should the hæmorrhages occur repeatedly or be 
prolonged they may organise and retinitis proliferans may result.

Papilloedema and papillitis may resolve spontaneously within a few weeks or months; two in this group cleared up with, and one did well without steroids.

Today corticosteroids should be given to all patients with fundal sarcoidosis. Systemic treatment is essential for topical applications do not influence fundal lesions. Choroiditis and perivasculitis usually respond rapidly to treatment and Alajouanine and others (1952) report the disappearance of pseudo-tumour and optic disc swelling. Scar tissue, retinitis proliferans and optic atrophy are unaffected by treatment.

All but two of the patients with choroiditis received steroids and none of those treated was deft with any visual defect. Of the two who had sarcoidosis before steroid treatment was available one had an eye enucleated and the other recovered.

\section{Summary}

Since corticosteroids have accelerated resolution of inflammation of the anterior segment of the eye, abnormalities of the fundus oculi are being more readily recognised in sarcoidosis.

In a series of 450 patients with sarcoidosis, 16 had fundal lesions comprising choroiditis (11 patients) papilloodema (3) and perivasculitis retinæ (2).

The majority received systemic corticosteroids. Treated patients had no residual complications. In one of three untreated patients, enucleation of the eye was necessary.

\section{REFERENCES}

Alajouanine, Th., Ferey, O., Houdart, R., and Ardoun, M. (1952): Form Neuro Oculaire de Besnier-BoeckSchaumann Amblyopie Rapide par Ateinte Successive des Deux Nerfs Opticue A Un Ale De Distance, Rev. Neurol., 86, 255 .

BRUNTSE, E. (1961): Ocular Sarcoidosis. Report of a Case with Fundus Changes, Acta ophthal. (Kbh), 39, 1040.

CoLOVER, J. (1948): Sarcoidosis with Involvement of the Nervous System, Brain, 71, 451.

Crick, R. P., Hoyle, C., and SMellie, H. (1961): The Eyes of Sarcoidosis, Brit. J. Ophthal., 45, 461.

DRESSLER, M., and WAGNER, H. (1941): Uber Zwei Falle Non Lymphgranulomatosis Benigne (Schaumann), Acta derm.-venerol. (Stáekh.), 22,511 .

FINE, M., and FlockS, M. (1953): Bilateral Acute Neuroretinitis with Sarcoidosis treated with Corticotropin and Cortisone, A.M.A. Arch. Ophthal., 50, 358.

FranceschetTI, A., and BABEL, J. (1949): La Chorio-Retinite En "Taches De Bougie" Manifestation De La Maladie De Besnier-Boeck, Ophthal., 118, 701.

Geeraets, W. J., McNeer, K. W., Maxey, E. F., and Guerry, D. (1962): Retinopathy in Sarcoidosis, Acta ophthal. (Kbh.), 40, 492.

Gifford, B. L., and KRAUSE, A. C. (1949): Differential Diagnosis of Boeck's Sarcoidosis (Report of 10 Cases with Ocular Involvement), A.M.A. Arch. Ophthal., 41, 667.

GoldBerG, S., and Newell, F. W. (1944): Sarcoidosis with Retinal Involvement, ibid, 32, 93.

Gould, H. L., and KaufMan, H. E. (1961): Boeck's Sarcoid of the Ocular Fundus, Amer. J. Ophthal., $52,633$.

GREEN, M. F., and KenNedY, R. J. (1957): Ocular Manifestations of Sarcoidosis, Cleveland Clin. Quart., 24, 10.

Hudelo, A., and Hudelo, J. (1962): Ocular Manifestations in Six Cases of Besnier-Boeck-Schaumann Sarcoidosis, Bull. Soc. Ophthal. Paris, 62, 21.

James, D. G., Anderson, R., Langley, D., and Ainslie, D. (1964): Ocular Sarcoidosis, Brit. J. Ophthal., 48, 461.

Klein, M., Calvert, R. I., Joseph, W. E., and Smith, E. (1955): Rarities in Ocular Sarcoidosis, Brit. J. Ophthal. 39, 416.

LANDERS, P. H. (1949): Vitreous Lesions Observed in Boeck's Sarcoid, Amer. J. Ophthal., 32, 1740.

LAVAL, J. (1952): Ocular Sarcoidosis, ibid, 35, 551.

LEVITT, J. M. (1941): Boeck's Sarcoid with Ocular Localization, Arch. Ophthal., 26, 358.

LEwIS, N. (1950): Ocular Manifestations of Sarcoidosis and Description of Seven Cases, Med. J. Aust., $2,582$.

LONGCOPE, W. T., and FreIMAN, D. G. (1952): Study of Sarcoidosis based on Combined Investigation of 160 Cases including 30 Autopsies from John Hopkins Hospital and Mass. Gen. Hops., Med. (Baltimore), $31,1$.

MeCKENSEN, G. (1952): Veranderungen Am Augenhinter Grund Bei Besnier-Boeck-Schaumannscher Erkrankung, Klin. Mbl. Augenheilk, 121, 51 .

MeITKE, H. (1958): A Rare Ocular Manifestation of Sarcoid, ibid, 133, 891.

MorAx, P. U. (1956): Les Localisations Neuro-Oculaires De La Reticuloendotheliose De Besnier-BoeckSchaumann, Ann. Oculist. (Paris), 189, 73.

OzAREWSKI, J. L., and BENNETT (1952): Ocular Sarcoidosis-Report of 3 Cases, Amer. J. Ophthal., $35,547$.

ROBERTS, W. I., and NIELSON, F. R. (1945): Uveoparotid Feyer with Bilateral Papilloedema, ibid, $289,1252$.

Ross, J. A. (1955): Uveoparotid Sarcoidosis with Cerebral Involvement, Brit. med. J., ii, 593.

WALSH, F. B. (1939): Ocular Importance of Sarcoid, Arch. Ophthal., 21, 421. 